\title{
Evaluation of Drip Irrigation Levels on Amaranthus (Amaranthus hybridus L) Yield and Water Use Efficiency under Shade-Net
}

\author{
Steven L. Peter*, M.S. Ayyanagowdar, B. Maheshwara Babu, \\ Y. Pampanna, B.S. Polisgowdar and G. Ramesh \\ Department of Soil and Water Engineering, College of Agricultural Engineering, Raichur \\ University of Agricultural Sciences, Raichur - 584 104, India \\ Corresponding author
}

\section{A B S T R A C T}

\section{Keywords}

Amaranthus, Drip irrigation levels, Water use efficiency and shade-net

Article Info

Accepted:

15 August 2019

Available Online:

10 September 2019
A field experiment was conducted from $23^{\text {rd }}$ March to $31^{\text {st }}$ May-2019 to evaluate the effect of drip irrigation levels on amaranthus (Amaranthus hybridus L) yield and water use efficiency under shade-net. The experiment was laid out in a randomized block design (RBD) with five treatments $(60 \%, 80 \%, 100 \%$ and $120 \%$ of water requirement using drip irrigation and $100 \%$ of water requirement using furrow irrigation) and four replications. The findings of the investigation revealed that the highest yields in terms of fresh leaves weight per plant $(63.89 \mathrm{~g})$, fresh stem weight per plant $(85.44 \mathrm{~g})$, economic yield per plant $(149.33 \mathrm{~g})$, fresh shoot weight per plant $(164.75 \mathrm{~g})$, fresh root weight per plant $(16.75 \mathrm{~g})$, fresh biomass $(330.83 \mathrm{~g})$ and economic yield per hectare $\left(22.69 \mathrm{t} \mathrm{ha}^{-1}\right)$ investigated for different irrigation treatments were obtained by irrigating amaranthus crop with $100 \%$ of water requirement using drip irrigation and the lowest economic yield per hectare $(14.20 \mathrm{t}$ $\mathrm{ha}^{-1}$ ) was obtained by irrigating the crop with $60 \%$ of water requirement using drip irrigation. The maximum and minimum water use efficiency $\left(7.95 \mathrm{~kg} \mathrm{~m}^{-3}\right)$ and $\left(3.89 \mathrm{~kg} \mathrm{~m}^{-}\right.$ ${ }^{3}$ ) were obtained by irrigating the crop with $80 \%$ of water requirement using drip irrigation and $100 \%$ of water requirement using furrow irrigation.

\section{Introduction}

Water scarcity is a major factor limiting agricultural production in arid and semi-arid regions (Dadrasan et al., 2015). Water use efficiency (WUE) in agriculture, commonly defined as biological or economical yield produced per unit of water consumed (Molden et al., 2010). Irrigation plays an important role in regulating plant growth and water use. The reduction of irrigation water and the increase of WUE without compromising the yield is increasingly crucial for agricultural sustainability (Choudhary et al., 2010 and Molden et al., 2010). Drip irrigation delivers irrigation water directly into the plant root zone slowly, precisely and continuously. Common irrigation methods practiced for vegetable production in most areas are furrow and basin. In general, the farmers over- 
irrigate, resulting in high water losses and low irrigation efficiencies, and thus creating drainage and salinity problems, all these mentioned problems are especially important in vegetable production in arid and semi-arid regions. Drip irrigation has advantages over conventional systems of irrigation as an efficient means of applying water, especially where water is limited, so water could be saved, crop quantity could be increased and quality can be improved.

Amaranthus (Amaranthus hybridus L.) originated in America and is one of the oldest food crops in the world. It is a very popular leafy vegetable in India as well as in tropical and subtropical areas of the globe. It is grown throughout the year since it has very quick growth and high yields of edible matter per unit area and it is suited for crop rotation. Amaranthus is highly tolerant to an arid environment. Amaranthus tender stems and leaves contains higher moisture $(85.70 \%)$ and nutritional components such as protein $(4.0 \mathrm{~g})$, fat $(0.50 \mathrm{~g})$, carbohydrates $(6.30 \mathrm{~g})$, calcium (397.0 mg), iron (25.5mg), phosphorus $(83.0$ $\mathrm{mg}$ ), vitamin A (9200 mg) and vitamin C (99 $\mathrm{mg}$ ), (Rai and Yadav, 2005) and it is also a good source of dietary fiber. Amaranthus is recommended as good food with medicinal properties for young children, lactating mothers and pettiness with constipation, fever, hemorrhage, anemia and xeropthalmia (Neth et al., 2002). It enhances mental development and stimulates the release of growth hormones, it helps in lowering cholesterol levels significantly in the blood hence it is advisable for children's consumption.

Most Leafy vegetable crops benefit from frequent irrigation throughout the season and are sensitive to water stress in which under irrigating can result to reduction of crop yields and over-irrigating in most cases can reduce the quality of the crop resulting into low marketable yields, therefore determination of irrigation level that when irrigation water applied to leafy vegetables will produce reasonable yields and saving water is crucial. Santosh et al., (2017) conducted research on drip irrigation levels and found that irrigating lettuce at 100 per cent of water requirement resulted in good crop growth and higher yields but (Ayas et al., 2011) reported highest yields when 75 per cent of pan evaporation water was applied. The use of greenhouse structures such as polyhouse and shade-net in production of leafy vegetables has reported ideal for crop cultivation throughout the year and better yields in terms of quantity and quality because greenhouse structures serve a purpose of protecting the crop against biotic (pests, diseases and weeds) and abiotic (temperature, humidity and light) stresses. Incorporating shade-net and drip irrigation will benefit more and more the crop by protecting it from high temperature especially in regions which experience high temperatures and drip may contribute substantially to the best use of water for agriculture and improving irrigation efficiency. Several researchers such as Rana et al., (2014), Isaac (2015), Nangare et al., (2015) and Santosh et al., (2017) have conducted researches to assess the performance of vegetable crops under greenhouse structures and found that the vegetable crops performed well inside greenhouse structures as compared to open field. In this study, different drip irrigation levels were evaluated and compared to furrow irrigation under shade-net on amaranthus crop yield and water use efficiency.

\section{Materials and Methods}

\section{Experimental site}

A field experiment was conducted from $23^{\text {rd }}$ March to $31^{\text {st }}$ May-2019 at the research field, College of Agricultural Engineering, University of Agricultural Sciences, Raichur. The experimental site is located at $\left(16^{\circ} 15^{\prime} \mathrm{N}\right.$ latitude, $77^{\circ} 20^{\prime} \mathrm{E}$ longitude) and at an elevation of $389 \mathrm{~m}$ above mean sea level 
(MSL). The climate is semi-arid and the average annual rainfall is $713 \mathrm{~mm}$. The maximum and minimum monthly means of temperature varied from 39.5 to $41.4^{\circ} \mathrm{C}$ and 26.1 to $27.6^{\circ} \mathrm{C}$ and other maximum and minimum monthly means weather parameters obtained from MARS and some maintained inside shade-net viz., relative humidity, sunshine hours, wind speed, light intensity and the potential evapotranspiration determined from CROPWAT 8.0 software. The quality of water used for irrigation had acceptable $\mathrm{pH}$ and EC values of 7.82 and $0.85 \mathrm{dS} \mathrm{m}^{-1}$ respectively according to Ayers and Westcot (1985) and the soil textural class of the soil was clay loam.

The field experiment was laid out in a randomized block design with five treatments and four replications under shade-net, Treatments $\mathrm{T}_{1}, \mathrm{~T}_{2}, \mathrm{~T}_{3}$ and $\mathrm{T}_{4}$ applied water to crop at $60 \%, 80 \%, 100 \%$ and $120 \%$ of crop water requirement through drip irrigation respectively and $\mathrm{T}_{5}$ applied water to a crop at $100 \%$ water requirement by using furrow irrigation. Drip irrigation plots had a net area of $0.9 \mathrm{~m}^{2}$ and gross area of $1.3 \mathrm{~m}^{2}$ (including spacing between plots) and furrow irrigation plots had gross area of $6.6 \mathrm{~m}^{2}$ which is $(8.8 \mathrm{~m}$ $\mathrm{x} 0.75 \mathrm{~m}$ ) furrow length $\mathrm{x}$ ridge to ridge width and the area of furrow was $2.64 \mathrm{~m}^{2}$ which is $(8.8 \mathrm{~m} \times 0.3 \mathrm{~m})$ furrow length $\mathrm{x}$ furrow width.

\section{Crop water requirement (WR)}

The daily water requirement for amaranthus crops was estimated by using Eq. 1

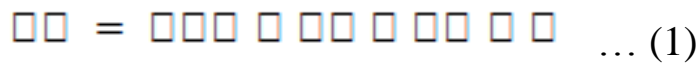$$
\text { Where, }
$$$$
\mathrm{WR}=\text { Water requirement }\left(\text { day }^{-1} \text { plant }^{-1}\right)
$$$$
\text { ETo }=\text { Reference evapotranspiration (Obtained }
$$$$
\text { from CROPWAT } 8.0 \text { software) }
$$$$
\mathrm{Kc}=\text { Crop factor }(0.7,1 \text { and } 0.95 \text { for early, }
$$$$
\text { development and maturity growth stages }
$$$$
\text { respectively) }
$$

$\mathrm{Cp}=$ Crop canopy factor (1 was considered for closely spaced crops)

Ap $=$ Plant area, $\mathrm{m}^{2}\left(0.04 \mathrm{~m}^{2}\right)$

\section{Irrigation requirement per treatment (Ir)}

For drip irrigation, irrigation requirement was calculated using Eq. 2

$\square \square=\frac{\square \square \square \square}{\square \square}$

Where,

$\mathrm{Ir}=$ Irrigation requirement per treatment

$\mathrm{N}_{\mathrm{p}}=$ Number of plants per treatment

$\mathrm{E}_{\mathrm{a}}=$ Application efficiency

\section{Irrigation time per treatment $\left(\mathbf{T}_{\mathrm{ir}}\right)$}

Irrigation time per treatment for drip irrigation plots was computed as per Eq. 3

$\square_{\square \square}=\frac{\square \square}{\square \square \square_{\square} \square \square_{\square}}$

Where,

$\mathrm{N}_{\mathrm{e}}=$ Number of emitters per lateral (22 emitters, same to all drip irrigation treatments) $\mathrm{N}_{1}=$ Number of laterals per treatment per bed $\left(\mathrm{N}_{1}=2\right.$ was used for all beds)

$\mathrm{q}=$ Emitter discharge (4 lph)

For different drip irrigation levels, the irrigation requirement per treatment (Ir) and the Irrigation time per treatment (Tir) above were multiplied by factors viz. 0.6, 0.8, 1 and 1.2 for $\mathrm{T}_{1}, \mathrm{~T}_{2}, \mathrm{~T}_{3}$ and $\mathrm{T}_{4}$ respectively.

\section{Depth of irrigation in furrow irrigation}

Furrows were formed and a slight slope was provided. The quantity of water to be delivered in furrow irrigation method was computed using Eq. 4

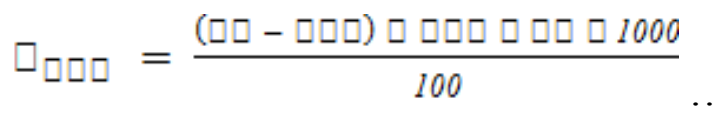


Where,

$\mathrm{d}_{\text {net }}=$ Net depth of water application per irrigation (mm) for amaranthus crop

$\mathrm{Fc}=$ Soil moisture at field capacity $(\%)$

PWP $=$ Soil moisture at permanent wilting point (\%)

Ds $=$ Bulk density of the soil $\left(\mathrm{g} \mathrm{cm}^{-3}\right)$

RZD = Root zone depth

$\square_{\square \square \square \square \square}=\frac{\square_{\square \square \square}}{\square_{\square}}$

Where,

$\mathrm{d}_{\text {gross }}=$ Gross depth $(\mathrm{mm})$

$\mathrm{E}_{\mathrm{a}}=$ Application efficiency

$\square \square=\frac{\square \square \square \square}{\square \square \square}$

Where,

$\mathrm{IF}=$ Irrigation frequency

ETc $=$ Crop evaporation $\left(\mathrm{mm} \mathrm{day}^{-1}\right)$

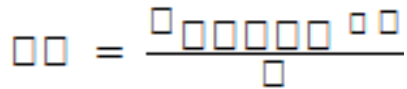

Where,

IT $=$ Irrigation duration per day

$\mathrm{q}=$ Stream size

$\mathrm{A}=$ Area of furrow $\left(2.64 \mathrm{~m}^{2}\right)$

\section{Water use efficiency (WUE)}

The water use efficiency of each treatment was computed using Eq. 8

$\square \square \square=\frac{\square}{C \square R}$

Where,

WUE $=$ Water use efficiency $\left(\mathrm{kg} \mathrm{m}^{-3}\right)$

$\mathrm{Y}=$ Crop yield $\left(\mathrm{kg} \mathrm{ha}^{-1}\right)$

CWR = Total quantity of water used per treatment $\left(\mathrm{m}^{3}\right)$

\section{Yield of amaranthus crop}

The yield parameters of amaranthus crop such as fresh leaves weight per plant, fresh stem weight per plant from tagged plants, economic yield per treatment were measured in four harvests, fresh root weight per plant and fresh shoot weight were measured during the last harvest. Fresh biomass, economic yield per plant and economic yield per hectare were calculated.

\section{Statistical analysis}

The analysis and interpretation of the data were done by using Analysis of Variance (ANOVA) technique by following the procedures given by Gomez and Gomez (1976). The value of significance used in ' $F$ ' and ' $\mathrm{t}$ ' test was at $5 \%$ probability level and wherever ' $F$ ' test was found significant, the ' $t$ ' test was performed to estimate critical difference among various treatments. The data were analyzed by using 'MS Excel' software.

\section{Results and Discussion}

\section{Yields of amaranthus crop}

\section{Fresh leaves weight, fresh stem weight and economic yield per plant}

The data on fresh leaves weight, fresh stem weight and economic yield per plant (g) presented in Table 1 were significantly affected by drip irrigation levels and furrow irrigation in shade-net. The significant highest and lowest fresh leaves weight per plant $(63.89 \mathrm{~g})$ and $(39.03 \mathrm{~g})$ were recorded from $\mathrm{T}_{3}$ and $\mathrm{T}_{5}$ respectively. Within drip irrigation treatments, the fresh leaves weight per plant were observed to increase as drip irrigation level increased and decreased at $\mathrm{T}_{4}$. The trend on fresh leaves weight per plant was in agreement with the findings obtained by Ejieji and Adeniran, (2010) in amaranthus cruentus, Santosh et al., (2017) in lettuce and Fawzy et al., (2019) in tomato crop. Similarly, $\mathrm{T}_{5}$ recorded the lowest fresh stem weight per plant $(50.34 \mathrm{~g})$, the highest significant fresh stem weight per plant $(85.44 \mathrm{~g})$ was recorded from $T_{3}$, followed by $T_{2}, T_{4}$ and $T_{1}$. The 
results on fresh stem weight per plant indicated an increasing trend as drip irrigation level increased from $T_{1}$ to $T_{3}$ and decreased at $\mathrm{T}_{4}$. Similar results on fresh stem weight per plant were reported by Ejieji and Adeniran, (2010). The lowest significant economic yield per plant $(89.35 \mathrm{~g})$ was recorded from $\mathrm{T}_{5}$, within drip irrigation treatments, the results on economic yield per plant indicated an increasing trend as drip irrigation level increased from $\mathrm{T}_{1}(100.32 \mathrm{~g})$ to $\mathrm{T}_{3}(149.33 \mathrm{~g})$ and decreased at $\mathrm{T}_{4}(106.5 \mathrm{~g})$.

\section{Fresh shoot weight and fresh root weight per plant}

The data on fresh shoot weight and fresh root weight per plant $(\mathrm{g})$ presented in Table 1 did not show a significant difference due to drip irrigation levels and furrow irrigation in shade-net. The highest fresh shoot weight per plant $(164.75 \mathrm{~g})$ was recorded from $\mathrm{T}_{3}$ followed by $\mathrm{T}_{2}(136.00 \mathrm{~g}), \mathrm{T}_{4}(119.00 \mathrm{~g}), \mathrm{T}_{1}$ $(118.75 \mathrm{~g})$ and the lowest fresh shoot weight per plant $(110.00 \mathrm{~g})$ was recorded from $\mathrm{T}_{5}$. This study also indicated that furrow irrigation recorded the lowest root fresh weight per plant $(10.00 \mathrm{~g})$ as compared to drip irrigation levels. Within drip irrigation levels, $\mathrm{T}_{3}$ recorded the highest fresh root weight per plant of $16.75 \mathrm{~g}$, followed by $\mathrm{T}_{2}(14.25 \mathrm{~g}), \mathrm{T}_{4}$ and $\mathrm{T}_{1}$ recorded the same weight of $11.00 \mathrm{~g}$. These findings fall in line with the findings obtained by Ejieji and Adeniran, (2010) and Kuslu et al., (2016) in which they reported an increase of fresh root weight as irrigation levels increased.

\section{Fresh biomass per plant}

The data on fresh biomass per plant $(\mathrm{g})$ as influenced by irrigation treatments under shade-net are presented in Table 1 and Figure 1. Fresh biomass significantly influenced with irrigation treatment, the lowest total fresh biomass of $209.36 \mathrm{~g}$ under shade-net was recorded from $\mathrm{T}_{5}$, within drip irrigation treatments, the highest significant fresh biomass per plant (330.83 g) was recorded from $\mathrm{T}_{3}$, followed by $\mathrm{T}_{2}(264.12 \mathrm{~g}), \mathrm{T}_{4}$ $(236.50 \mathrm{~g})$ and lowest in $\mathrm{T}_{1}(230.08 \mathrm{~g})$. The results on fresh biomass were increasing as drip irrigation level increased and decreased at $\mathrm{T}_{4}$, this can be explained by the increase of fresh leaves weight per plant, fresh stem weight per plant, root weight and shoot weight per plant which had the same response on drip irrigation levels and hence the same trend obtained for fresh biomass per plant.

\section{Economic yield per hectare}

Economic yield per hectare $\left(\mathrm{t} \mathrm{ha}^{-1}\right)$ as influenced by drip irrigation levels and furrow irrigation under shade-net are presented in Table 1 and Figure 2. The highest significant economic yield per hectare $\left(22.69 \mathrm{t} \mathrm{ha}^{-1}\right)$ was recorded from $\mathrm{T}_{3}$, followed by $\mathrm{T}_{2}$ (19.64 $\mathrm{tha}$ $\left.{ }^{1}\right), \mathrm{T}_{4}\left(15.29 \mathrm{t} \mathrm{ha}^{-1}\right), \mathrm{T}_{5}\left(15.10 \mathrm{t} \mathrm{ha}^{-1}\right)$ and $\mathrm{T}_{1}$ $\left(14.20 \mathrm{t} \mathrm{ha}^{-1}\right)$. The findings of this study are in agreement with the results obtained by Santosh et al., (2017) in which the economic yields of lettuce increased as irrigation levels increased and decreased at 120 per cent of water application.

The tendency of increasing yields due to increased drip irrigation levels observed in this study can be explained by the fact that, increasing drip irrigation level from $T_{1}$ to $T_{3}$ was increasing the growth parameters such as number of leaves, number of branches, stem length, stem diameter, leaf length, leaf width, leaf area, leaf area index and root length and decreased when the plant provided with more than the water requirement at $\mathrm{T}_{4}$. Dodd (2008) showed that increasing water supply to the plants resulted in low levels of abscisic acid (ABA) which caused stomatal opening, hence increased photosynthetic capacity of the leaves and increased growth. 
Table.1 Effect of drip irrigation levels on yield and water use efficiency (WUE) of amaranthus crop under shade-net

\begin{tabular}{|c|c|c|c|c|c|c|}
\hline Treatments & $\begin{array}{l}\text { Fresh leaves weight } \\
\text { per plant (g) }\end{array}$ & $\begin{array}{l}\text { Fresh stem weight } \\
\text { per plant (g) }\end{array}$ & $\begin{array}{l}\text { Economic yield } \\
\text { per plant (g) }\end{array}$ & $\begin{array}{l}\text { Fresh shoot weight } \\
\text { per plant (g) }\end{array}$ & $\begin{array}{l}\text { Fresh root weight } \\
\text { per plant (g) }\end{array}$ & $\begin{array}{c}\text { Fresh biomass } \\
\text { per plant }(\mathrm{g})\end{array}$ \\
\hline T1: $60 \%$ ET & 43.07 & 57.27 & 100.33 & 118.75 & 11.00 & 230.08 \\
\hline T2: $80 \%$ ET & 48.98 & 64.90 & 113.87 & 136.00 & 14.25 & 264.12 \\
\hline T3: 100\% ET & 63.89 & 85.44 & 149.33 & 164.75 & 16.75 & 330.83 \\
\hline T4: $120 \%$ ET & 45.55 & 60.96 & 106.50 & 119.00 & 11.00 & 236.50 \\
\hline T5: Furrow & 39.03 & 50.34 & 89.36 & 110.00 & 10.00 & 209.36 \\
\hline S.Em \pm & 2.79 & 3.76 & 6.53 & 15.14 & 1.82 & 19.27 \\
\hline $\mathrm{CD}(0.05)$ & 8.61 & 11.59 & 20.11 & 46.64 & 5.60 & 59.38 \\
\hline & $\mathrm{S}$ & $S$ & $\mathrm{~S}$ & NS & NS & $\mathrm{S}$ \\
\hline Treatments & $\begin{array}{l}\text { Economic yield per } \\
\text { treatment }(\mathbf{k g})\end{array}$ & \multicolumn{2}{|c|}{$\begin{array}{l}\text { Economic yield per hectare } \\
\qquad\left(\mathrm{t} \mathrm{ha}^{-1}\right)\end{array}$} & $\begin{array}{l}\text { Total Water applied } \\
\qquad\left(\mathrm{m}^{3} \mathrm{ha}^{-1}\right)\end{array}$ & \multicolumn{2}{|c|}{$\begin{array}{l}\text { Field water use efficiency } \\
\qquad\left(\mathrm{kg} \mathrm{m}^{-3}\right)\end{array}$} \\
\hline T1: 60\% ET & 16.25 & \multicolumn{2}{|r|}{14.20} & \multicolumn{2}{|c|}{1887.434} & 7.52 \\
\hline T2: $80 \%$ ET & 22.46 & & 19.64 & 2468.69 & & 7.95 \\
\hline T3: $100 \%$ ET & 25.96 & & 22.69 & 3125.77 & & 7.26 \\
\hline T4: $120 \%$ ET & 17.50 & & 15.29 & 3601.28 & & 4.25 \\
\hline T5: Furrow & 9.96 & & 15.10 & 3880.00 & & 3.89 \\
\hline S.Em \pm & 0.75 & & 0.83 & & & \\
\hline $\mathrm{CD}(0.05)$ & 2.32 & & 2.57 & & & \\
\hline & S & & $\mathrm{S}$ & & & \\
\hline
\end{tabular}

Note: $\mathrm{S}=$ Significant at $5 \%$ probability level, $\mathrm{NS}=$ Non significant at $5 \%$ probability level 
Fig.1 Effect of drip irrigation levels on total biomass per plant $(\mathrm{g})$

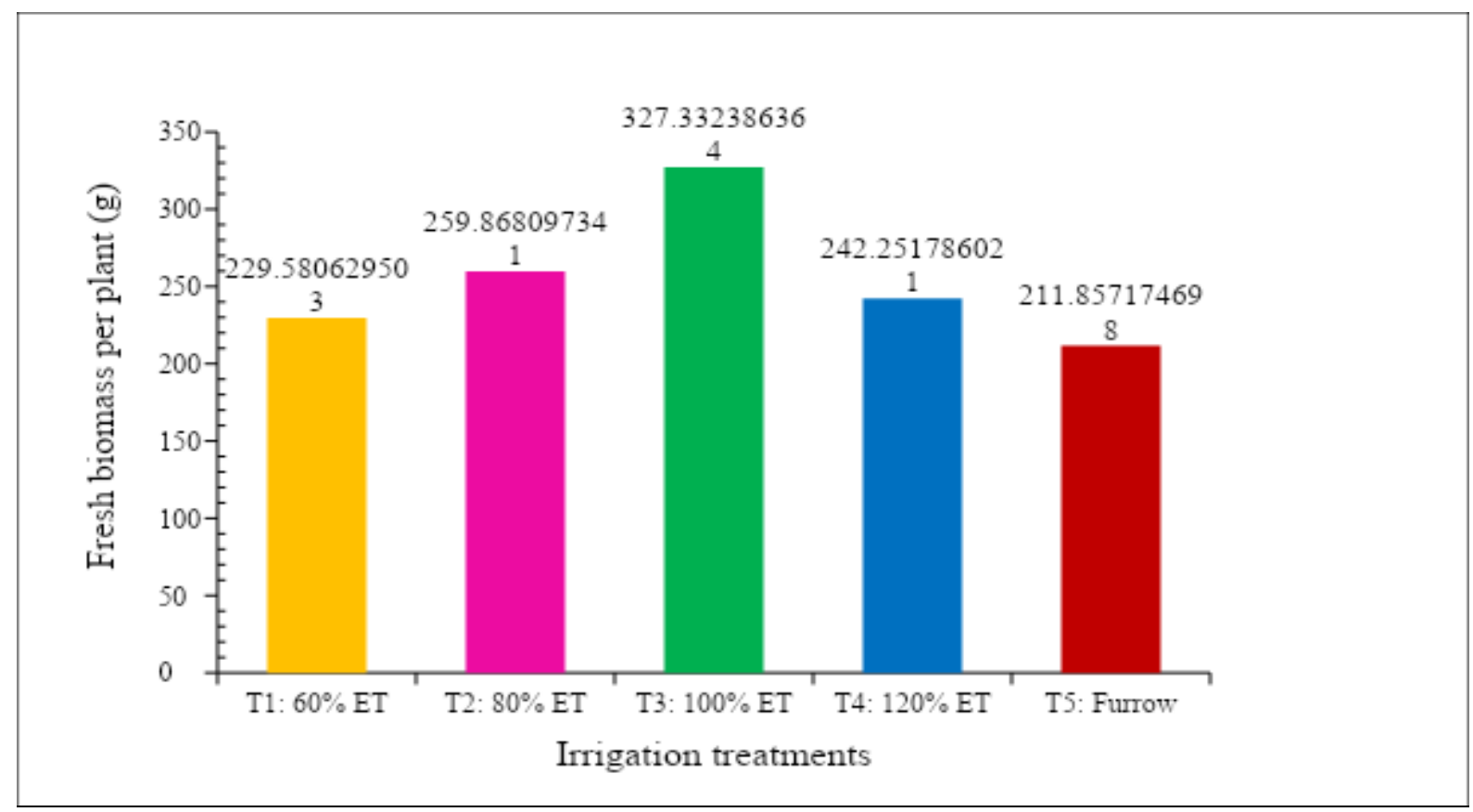

Fig.2 Effect of drip irrigation levels on economic yield per hectare $\left(\mathrm{t} \mathrm{ha}^{-1}\right)$

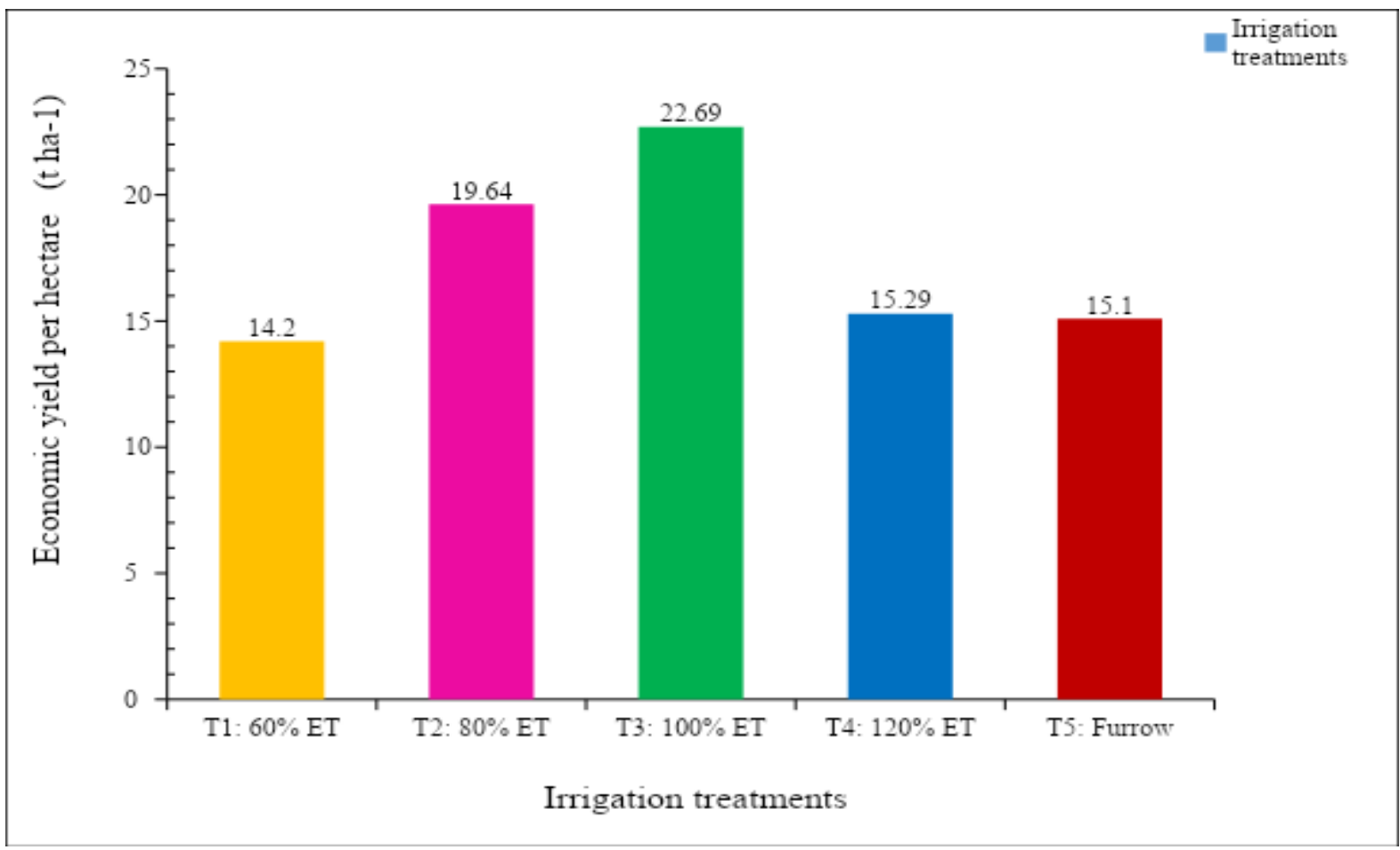

The reduction of yield in $\mathrm{T}_{4}$ when drip irrigation was higher than the required quantity of water by 20 per cent, this can be explained by the fact that, over-irrigation results into excessive soil moisture which prevents circulation of oxygen hence 
preventing roots to properly extract water and nutrients and hence poor growth and yield and lowest yields obtained from furrow irrigation can be explained by the fact that, frequent irrigation in drip irrigation resulting in even distribution of soil moisture in the root zone of the crop hence good growth and yields.

\section{Water use efficiency of amaranthus crop}

Field water use efficiency expresses how much crop yields can be produced for the quantity of water used in the field for the production of the crop. The results in this study indicated that drip irrigation levels $T_{2}$ $\left(7.95 \mathrm{~kg} \mathrm{~m}^{-3}\right), \mathrm{T}_{3}\left(7.26 \mathrm{~kg} \mathrm{~m}^{-3}\right)$ and $\mathrm{T}_{4}(4.25$ $\mathrm{kg} \mathrm{m}^{-3}$ ) had higher field water use efficiency than furrow irrigation $\mathrm{T}_{5}\left(3.89 \mathrm{~kg} \mathrm{~m}^{-3}\right)$ this can be because of low quantity of water applied and the high yields obtained by $\mathrm{T}_{2}, \mathrm{~T}_{3}$ and $\mathrm{T}_{4}$ and the higher field water use efficiency obtained by $\mathrm{T}_{1}\left(7.52 \mathrm{~kg} \mathrm{~m}^{-3}\right)$ as compared to $\mathrm{T}_{5}$ can only be explained by less quantity of water used by $\mathrm{T}_{1}$.

It is concluded by considering the interests of farmers, the appropriate drip irrigation levels have to be selected which will increase the yields of amaranthus crop and reduce water consumptions. Two options are provided from the treatments investigated, first irrigating amaranthus crop by providing water at 80 per cent of water requirement using drip irrigation especially in arid and semi-arid regions where water scarcity is prominent and second irrigating amaranthus crop by providing water at 100 per cent of water requirement using drip irrigation. In the present study, irrigating with $\mathrm{T}_{2}$ yielded $19.64 \mathrm{t} \mathrm{ha}^{-1}$ and saved water by $39.6 \%$ and also $\mathrm{T}_{3}$ yielded $22.69 \mathrm{t} \mathrm{ha}^{-1}$ and saved water by $26.8 \%$ from furrow irrigation.

\section{Acknowledgement}

Authors are thankful to the Department of Soil and Water Engineering, UAS, Raichur for their support during the course of the research and highly thankful to ICAR for providing financial assistance to conduct this research.

\section{References}

Ayas, S., Orta, H. and Yazgan, S., 2011. Deficit irrigation effects on broccoli (Brassica oleracea L.) yield in unheated greenhouse condition. Bulg. J. Agric. Sci., 17: 551-559

Ayers, R. S. and Westcot, D. W., 1985. Water quality for agriculture. Rome: Food and Agriculture Organisation Irrigation and Drainage Paper 29.

Choudhary, O. P., Ghuman, B. S., Dhaliwal, M. S. and Chawla, N., 2010. Yield and quality of two tomato (Solanum lycopersicum L.) cultivars as in xuenced by drip and furrow irrigation using waters having high residual sodium carbonate. Irrig. Sci., 28: 513-523

Dadrasana, M., Chaichi, M. R., Pourbabaee, A. A., Yazdani, D. and KeshavarzAfshar, R., 2015. Deficit irrigation and biological fertilizer influence on yield and trigonelline production of fenugreek. Industrial Crops and Products, 77: 156-162

Dodd, I. C., 2008. Measuring and modeling xylem ABA Concentration in tomato plants exposed to conventional deficit irrigation and partial rootzone drying. Acta Hort., 792: 225-232.

Ejieji, C. J. and Adeniran, K. A., 2010. Effect of water and fertilizer stress on the yield, fresh and dry matter production of grain amaranth (Amaranthus. cruentus). Australian J. Agric. Engg., 1(1): 18-24.

Fawzy, Z. F., Ragab, M. E., Arafa, Y. E., Sawan, O. M. and El-Sawy, S. M., 2019. Effect of irrigation systems on vegetative growth, fruit yield, quality and irrigation water use efficiency of 
tomato plants (Solanum lycopersicum L.) grown under water stress conditions. Acta Scientific Agriculture, 3(4): 172183.

Gomez, K. A. and Gomez, A. A., 1976. Statistical procedures for agricultural research ( $2^{\text {nd }}$ edition), Int. Rice Res. Inst, Phi., pp 85-89.

Isaac, S. R., 2015. Performance evaluation of leafy vegetables in naturally ventilated polyhouses. Int. J. Research Studies in Agric Sci., 1(3): 1-4.

Kuslu, Y., Sahin1, U., Kiziloglu, F. M. and Sengul, M., 2016. Yield and quality responses of drip-irrigated spinach to different irrigation quantities in a semiarid region with a high altitude. $J$. Central European Agriculture, 17(3): 763-777.

Molden, D., Oweis, T., Steduto, P., Bindraban, P., Hanjra, M. A. and Kijne, J., 2010. Improving agricultural water productivity: Between optimism and caution. Agric. Water Mgt., 97: 528-
535

Nangare, D. D., Jitendra, S., Meena, V. S., Bharat, B. and Bhatnagar, P. R., 2015. Effect of green shade-nets on yield and quality of tomato (Lycopersicon esculentum Mill) in a semi-arid region of Punjab. Asian J. Advances in Basic and App. Sci., 1(1): 1-8.

Neth, P., Vecayndhan and Singh, B. P. 2002. Vegetables for the tropical region. ICAR, New Delhi.

Rai, N. and Yadav, D. S., 2005. Advances in vegetable production. Research co Book Centre New Delhi, 530-531.

Rana, N., Kumar, K., Walia, A. and Sharma, S., 2014. Tomato Fruit Quality under Protected Environment and Open Field Conditions. Int. J. Bio-res. and Stress Mgt., 5(3): 422-426.

Santosh, D. T., Reddy, R. G. and Tiwari, K. N., 2017. Effect of drip irrigation levels on yield of lettuce under polyhouse and open field condition. Int. J. Curr. Microbiol. App. Sci., 6(7): 1210-1220.

\section{How to cite this article:}

Steven L. Peter, M.S. Ayyanagowdar, B. Maheshwara Babu, Y. Pampanna, B.S. Polisgowdar and G. Ramesh. 2019. Evaluation of Drip Irrigation Levels on Amaranthus (Amaranthus hybridus L) Yield and Water Use Efficiency under Shade-Net. Int.J.Curr.Microbiol.App.Sci. 8(09): 318-326. doi: https://doi.org/10.20546/ijcmas.2019.809.038 